\title{
Factors Influencing the Regional Dynamics of Butternut Canker
}

\author{
Kishan R. Sambaraju, ${ }^{\dagger}$ Pierre DesRochers, and Danny Rioux, Natural Resources Canada, Canadian Forest Service, Laurentian Forestry
} Centre, Stn. Sainte-Foy, Québec, QC G1V 4C7, Canada

\begin{abstract}
Butternut (Juglans cinerea) is an important component of native biodiversity in eastern North America. Of urgent concern is the survival of butternut, whose populations are declining rapidly, in large part due to an exotic pathogen, Ophiognomonia clavigignenti-juglandacearum, that causes butternut canker. The disease presently occurs throughout the range of butternut in North America, causing branch and stem cankers, dieback, and tree mortality. Despite the existential threat posed by o. clavigignenti-juglandacearum to butternut, a detailed understanding of the factors that drive cross-scale disease patterns is lacking. Therefore, we investigated the association of a range of factors, including tree

attributes, topography, and weather, with butternut canker spatial dynamics at different scales using data collected in the province of Quebec, Canada. Trunk canker damage and dieback showed distinct geographic patterns. Bark phenotype was not significantly associated with trunk canker damage. Results suggest that open or dominant trees may show less dieback than intermediate or suppressed trees. Probability of the presence of trunk canker and percent dieback were proportional to the tree diameter at breast height. Temperature was positively associated with disease severity at a $1-\mathrm{km}^{2}$ scale. Our results provide strong evidence that multiple factors, notably weather, influence butternut canker epidemiology.
\end{abstract}

Butternut (Juglans cinerea L.) is a tree species native to eastern North America. A member of the walnut family (Juglandaceae), which includes other important tree species such as black walnut (J. nigra L.), Persian or English walnut (J. regia L.), and pecan (Carya illinoinensis (Wangenh.) K. Koch), butternut often occurs as scattered, individual trees, or sometimes in groups, in the mixed hardwood forests of its native range (Farrar 1995). Butternut is found in the provinces of Ontario, Quebec, and New Brunswick in Canada whereas, in the United States, it occurs within a broad geographical region that encompasses the northeastern United States from New England to Georgia on the East Coast to the west from Minnesota down to Arkansas (Farrar 1995; Ostry et al. 1994; Rink 1990). This moderate-sized (12- to 25-m), short-lived (approximately 75 years) tree species is shade intolerant and needs abundant sunlight for proper growth and reproduction (Farrar 1995; Rink 1990). Butternut trees are important components of the forests of eastern North America and provide ecological, economic, and social benefits. For instance, butternut supplies nutritious nuts for wildlife and human consumption. Butternut wood is used for making cabinets, furniture, and veneer; butternut wood is also preferred for carving (Woeste and Pijut 2009). Finally, native American tribes use butternut husks for making dyes, while butternut bark and nuts are used for medicinal purposes (Krochmal and Krochmal 1982).

Of critical concern presently, however, is the very survival of this tree species that faces extirpation primarily due to butternut canker, which is caused by an exotic fungus, Ophiognomonia clavigignentijuglandacearum (V. M. G. Nair, Kostichka, \& J. E. Kuntz) Broders $\&$ G. J. Boland, established throughout the range of butternut in North America (Davis et al. 1992; Farlee et al. 2010a; Harrison et al. 1998; Innes and Rainville 1996; Nielsen et al. 2003). This pathogen has caused moderate to very severe decline in butternut populations in many parts of the United States and Canada, and has severely impacted regeneration in the affected regions (Fleguel 1996). In view of the

${ }^{\dagger}$ Corresponding author: K. R. Sambaraju;

E-mail: Kishan.Sambaraju@ canada.ca

This project was funded by Natural Resource Canada and by the Interdepartmental Recovery Fund of Environment and Climate Change Canada.

*The $\boldsymbol{e}$-Xtra logo stands for "electronic extra" and indicates that one supplementary table and three supplementary figures are published online.

Accepted for publication 27 October 2017.

(c) 2018 The American Phytopathological Society threat to its survival, butternut is listed variously (e.g., species of special concern, vulnerable, and so on) in many states in the United States, although federally it is yet to be listed (Woeste et al. 2009). In Canada, butternut is designated as an "Endangered" species by the federal Species at Risk Act since November 2003 (Nielsen et al. 2003).

The place of origin and the year and mode of introduction of O. clavigignenti-juglandacearum into North America are unknown. The dominant view is that the fungus was introduced into North America recently (Furnier et al. 1999), possibly through multiple independent events (Broders et al. 2012), although some authors opine that $O$. clavigignenti-juglandacearum may have been present since the early 20th century and that its disease symptoms may have been misattributed to the closely associated secondary pathogen Juglanconis oblonga (Berk.) Voglmayr \& Jaklitsch, comb. nov. (formerly Melanconis juglandis (Ellis \& Everh.) A. H. Graves; anamorph: Melanconium oblongum Berk.) (Broders et al. 2015; Brosi 2010; Ostry and Woeste 2004; Voglmayr et al. 2017). Nevertheless, the first report of widespread butternut mortality was from southwest Wisconsin in 1967 (Renlund 1971), which was later ascribed to a disease caused by a fungus (Kuntz et al. 1977). The disease spread rapidly thereafter and, by 1977, it had been found in 14 of 16 surveyed states in the eastern United States (Anderson and LaMadeleine 1978). The causal fungal pathogen, Sirococcus clavigignenti-juglandacearum, was described more than a decade after the initial report by Nair et al. (1979). Broders and Boland (2011) later reclassified the butternut canker fungus as $O$. clavigignentijuglandacearum. In Canada, butternut canker was first reported from Quebec in 1990 (Innes and Rainville 1996), from Ontario in 1991 (Davis et al. 1992), and from New Brunswick in 1997 (Harrison et al. 1998). The disease is believed to exist in most butternut-growing regions in Canada, with fresh sightings of the disease being sporadically reported from both within (e.g., natural forests) and beyond (e.g., plantations) the range of butternut in Canada (MFFPQ 2016; NBDNR 2014).

Initial infection of butternut trees by $O$. clavigignenti-juglandacearum usually starts when conidia gain entry into the tree via openings in branches in the lower crown such as lenticels, leaf scars, wounds, cracks in the bark, and so on (Nair et al. 1979). Elongated sunken cankers are subsequently formed on the infected twigs. Hyphal pegs arising from the under-bark stroma and that contain fruiting bodies rupture the bark of the twig. Thus, extruded conidia may be carried down the tree to the trunk and root collar region by rain splashes or via water runoff, where they infect the inner bark, causing cankers. Trunk cankers are depressed areas visible on the bark that have a black, inky inner region, occasionally surrounded by a whitish boundary. Trunk cankers eventually cause tree mortality by coalescing and girdling the stem. The disease may spread from diseased trees to neighboring healthy trees via spores dispersed 
through aerosols generated during rain (Tisserat and Kuntz 1983a), insects (Halik and Bergdahl 2002), rodents, and birds. The pathogen is fruitborne in butternut (Broders and Boland 2010; Innes 1998).

O. clavigignenti-juglandacearum infects all butternut trees, regardless of their age or size (Brosi 2010). Other closely related members in the family Juglandaceae are susceptible to infection by $O$. clavigignenti-juglandacearum as well, although infections may not necessarily cause tree mortality. For instance, $O$. clavigignentijuglandacearum can infect eastern black walnut (J. nigra) (Innes and Rainville 1996; Ostry et al. 1997) and heartnut (J. ailantifolia var. cordiformis) (Ostry 1997). Persian walnut (J. regia) is highly susceptible (Orchard et al. 1982; Ostry and Moore 2007), whereas pure Japanese walnut (J. ailantifolia), heartnut, and their hybrids with butternut (known as buartnuts, $J . \times$ bixbyi Rehd.) (Farlee et al. 2010b), are more resistant to $O$. clavigignenti-juglandacearum infection than pure butternut trees (Orchard et al. 1982). Interestingly, putatively resistant butternut trees may be found interspersed with heavily diseased ones in their native habitat (Ostry et al. 2003). Putatively resistant trees often have coarse, deeply furrowed bark whereas susceptible ones usually have smooth bark; however, disease dynamics can vary based on other tree factors and site-related variables. Previous studies have described the interrelationships of butternut health variables with tree and habitat characteristics (Boraks and Broders 2014; Brosi 2010; Parks et al. 2013; RossDavis et al. 2008), and with genetic structure of butternut (Parks et al. 2014). However, they largely did not take into account the correlations between the possible multivariate disease responses, consider intersite variabilities, or tease apart the effects of individual factors after accounting for the influences of others. Therefore, more detailed analyses that consider the above issues in statistical models are needed to identify important factors that influence the magnitude of the disease across different spatial scales. Understanding these associations is critical in efforts made to identify, conserve, and restore butternut and save it from extinction in North America.

A major knowledge gap in our understanding of butternut canker epidemiology is the role played by weather-related variables such as temperature, relative humidity $(\mathrm{RH})$, and precipitation at a large scale. Although a rigorous quantification of weather influences on butternut canker is lacking, previous investigations into this subject area do provide clues to conditions that could favor the development and spread of the disease on the landscape. For example, Tisserat and Kuntz (1983b) found that spore viability (i.e., mean germination) was higher at 13 than at $25^{\circ} \mathrm{C}$ for similar conditions, such as vapor pressure deficit, a parameter linked to RH. Laboratory studies by Moore and Ostry (2015) showed that spore germination occurs over a wide range of temperatures $\left(4\right.$ to $32^{\circ} \mathrm{C}$ ), with $>80 \%$ germination occurring within 3 days at temperatures of 20 to $28^{\circ} \mathrm{C}$. Viability of conidia growing at 20 and $28^{\circ} \mathrm{C}$ is rapidly reduced at an RH of 40 or $90 \%$ (Moore and Ostry 2015). In accordance with the findings reported by Tisserat and Kuntz (1983b), viability of conidia is higher at 12 than at $28^{\circ} \mathrm{C}$. Conidia can survive up to 21 days at subsaturated $\mathrm{RH}$ levels and for a potentially much longer period in water (Moore and Ostry 2015). Precipitation plays an essential role in close-distance spore dispersal (Tisserat and Kuntz 1983a). These authors, for instance, demonstrated that conidia could be disseminated up to $40 \mathrm{~m}$ under rainy conditions. However, to our knowledge, no study has established a definite link between different weather variables and butternut canker severity in the field, especially at a regional scale, which we sought to determine in this work.

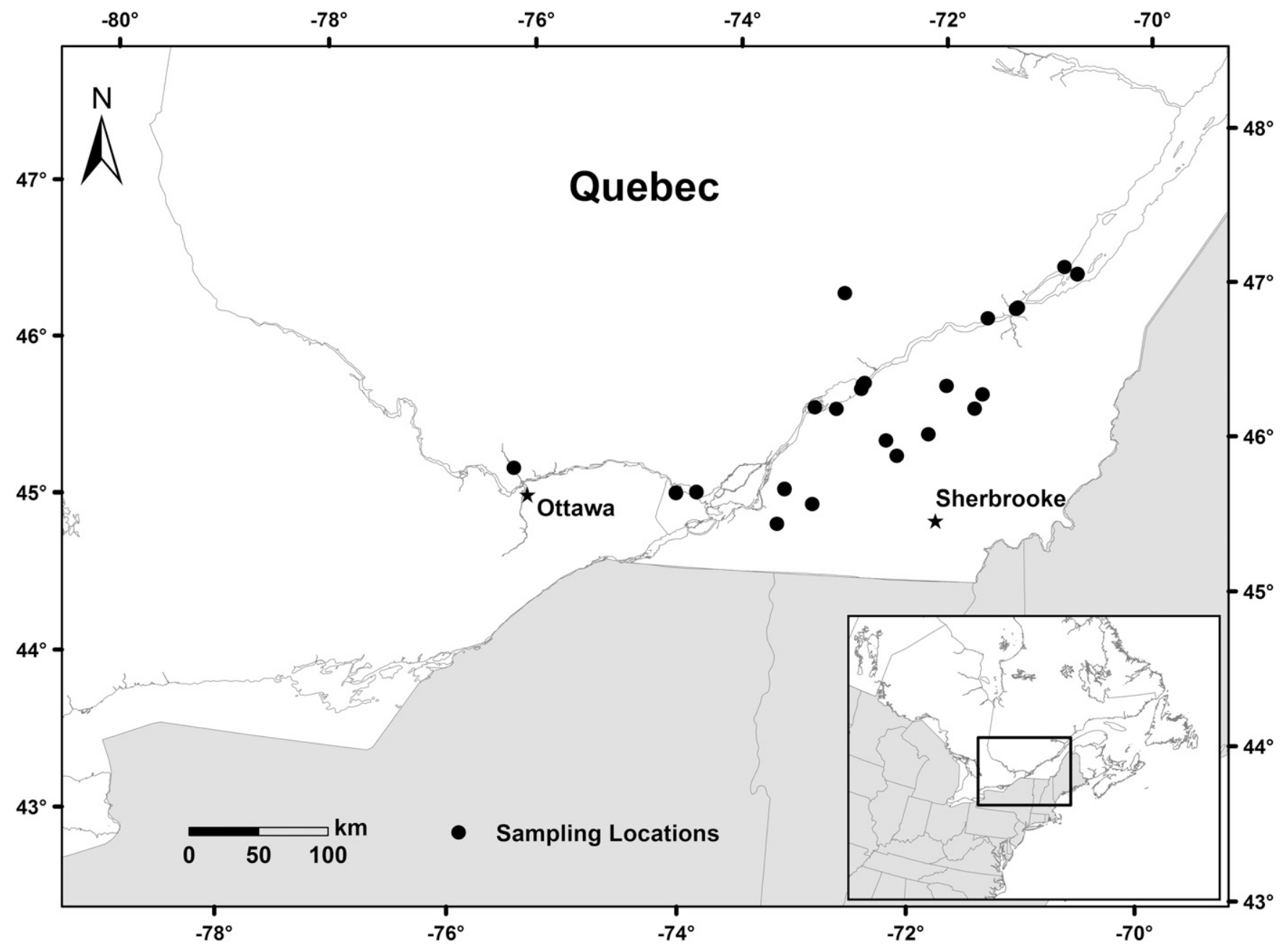

Fig. 1. Butternut canker survey locations in the province of Quebec, Canada. 
Specifically, the aims of our study were to (i) gain a better understanding of the relationships between butternut trunk canker or dieback and tree-level phenotypic, geographic, or topographic variables; (ii) explore the association between weather and diseaserelated indices in order to identify the most important weather drivers of the disease at a coarse scale; and (iii) develop predictive multiple regression models of disease indices based on selected meteorological variables.

\section{Materials and Methods}

Study area and data collection. Butternut canker data used in our study were collected from several locations in the province of Quebec, Canada, between 2006 and 2012 via collaborative surveys led by the Canadian Forest Service in partnership with several agencies (see Acknowledgments). A map of data collection sites, plotted based on average values of tree coordinates per site, is presented in Figure 1. Data were collected using a standard guide that provided instructions for recording information on tree location, tree attributes (e.g., crown class, bark phenotype, and so on), and various health-related parameters, with brief descriptions and figures to help contrast healthy trees with diseased ones (P. DesRochers, K. Harrison, A. Hopkin, L. Morneau, and R. Wilson, unpublished report). Global Positioning System devices were used to record tree coordinates (latitude and longitude), which were determined at the level of the tree in most cases. However, in some locations, tree coordinates were determined at a single point for a given location (e.g., when butternut trees were in close proximity to each other). For consistency, spatial coordinates that were not recorded in decimal degree format were converted into decimal degrees (e.g., $46.2742^{\circ},-71.8572^{\circ}$ ) using TRX software (Natural Resources Canada, Ottawa, ON, Canada). Specific tree-related data that were collected and further processed included bark phenotype (uncertain; smooth or not deeply furrowed, light gray [Supplementary Fig. S1]; or coarse, deeply furrowed, dark gray [Supplementary Fig. S2]), dominance (open, dominant, codominant, intermediate, or suppressed), and diameter at breast height (DBH, in centimeters). Disease-related information used in the analyses included data on trunk canker damage (Table 1) and dieback (Table 2). Trunk damage was rated based on the method developed by Ostry et al. (1994). Dieback ratings followed the classification system of Millers et al. (1991). In brief, two trained observers rated the condition of the twigs $(\leq 2.5 \mathrm{~cm}$ ) within the canopy and at the tree margins, each on opposite sides of a tree, for loss of foliage or death. Dead twigs at the base of the canopy and "snags" (i.e., dead branches without twigs measuring $\leq 2.5 \mathrm{~cm}$ diameter) were not considered during rating. Most of the preceding tree parts were believed to have died or become moribund because of lack of sufficient exposure to sunlight. Each observer then provided a visual estimate of percent dieback. The overall rating was based on a consensus between the two observers' estimation of percent tree dieback with an acceptable level of variability of \pm 1 class code in case of a disagreement (Table 2). Occasionally, butternut trees were rated by a single observer. Data management and statistical analysis in this study were performed using SAS (v. 9.3; SAS Institute, Cary, NC). We used ArcGIS (v. 10.2; ESRI, Redlands, CA) for spatial data management, analysis, and mapping. Data for the different variables were collected from 24 locations ( $n=746$ trees) between 2006 and 2012, except for phenotype data,

Table 1. Trunk canker damage classification used for butternut trees affected by Ophiognomonia clavigignenti-juglandacearum in Quebec (modified from Ostry et al. 1994)

\begin{tabular}{lll}
\hline Class & \multicolumn{1}{c}{ Description } & Midclass proportion \\
\hline 0 & $\begin{array}{c}\text { No damage on the main stem } \\
\text { Less than 25\% of the main stem's } \\
\text { circumference girdled }\end{array}$ & 0 \\
2 & $\begin{array}{c}25 \text { to 50\% of the main stem's circumference } \\
\text { girdled }\end{array}$ & 0.125 \\
3 & $\begin{array}{c}50 \text { to 75\% of the main stem's circumference } \\
\text { girdled }\end{array}$ & 0.625 \\
4 & $\begin{array}{l}\text { Over 75\% of the main stem's circumference } \\
\text { girdled }\end{array}$ & 0.875 \\
\hline
\end{tabular}

which were not collected during the first year of the survey (2006). We did not consider other butternut populations in North America outside Quebec in our analyses because it was beyond the scope of this work and we wanted to study potential regional drivers of the disease. Moreover, detailed butternut health data such as ours are often unavailable or are difficult to acquire range-wide for large-scale modeling analysis. In this article, the term "severity" generically refers to the overall magnitude of the disease. Descriptive statistics concerning overall butternut health in southern Quebec will be published elsewhere.

Tree-level analysis of disease severity. Data were analyzed in a multilevel modeling framework using the GLIMMIX procedure in SAS (v. 9.3). Multilevel models are especially useful in situations where data are organized hierarchically (i.e., at progressively higher levels); for example, outcomes from trees nested within locations, data collected over time from individual trees, which may be further nested within locations, and so forth. We used shared random intercept multivariate generalized linear mixed models (GLMM) to simultaneously assess the relationship of the two "within-tree" potentially correlated responses, namely dieback and canker damage: "level-1" unit (Goldstein 1995) as a function of "level-2" explanatory variables determined at the tree level (e.g., phenotype and dominance), and a "level-3" variable to account for variation at the location level via a random intercept term for location. The shared random intercept accounts for any correlation between the two responses (Jaffa et al. 2016) and indicates variation in the linearized mean values of the responses between locations. For easier interpretation and to reduce estimation problems, we simplified the analyses by performing multivariate analyses using the presence or absence of trunk canker on a tree (binary variable) and arcsine square root-transformed percentage of dieback rating (i.e., class codes) as the two dependent variables. We deemed it reasonable to analyze dieback as a continuous variable because (i) dieback class codes essentially represent visual estimates of percent dieback and (ii) current functionality in PROC GLIMMIX does not allow for analysis of binary and ordinal responses simultaneously. Also, we believed that dieback as a single continuous measure would be useful for developing an overall index of disease severity for butternut canker. Elevation and slope for the point data of tree occurrences were extracted using the Canadian Digital Elevation Model (http://open.canada.ca/data/en/ dataset/7f245e4d-76c2-4caa-951a-45d1d2051333) through BioSIM, v. 11 (Régnière 1996; Régnière and St-Amant 2007). Latitude (decimal degrees), longitude (negative decimal degrees), elevation (meters), and slope (degrees) were each centered at their minimum value across the study area for easier interpretation of the intercept and to avoid computational challenges (e.g., convergence issues) during model fitting. Latitude and elevation were considered strong proxies for temperature and precipitation, respectively, in this analysis. Phenotype data were binary; that is, 0 indicated coarse-bark phenotype (the reference) and 1 indicated smooth-bark phenotype. Dominance was categorized into three classes: (i) intermediate or suppressed (reference group), (ii) codominant, and (iii) dominant or open. Butternut cannot tolerate

Table 2. Dieback rating methodology and ranges of acceptable variability between observers used in this study when estimating dieback caused by Ophiognomonia clavigignenti-juglandacearum in Quebec (P. DesRochers, K. Harrison, A. Hopkin, L. Morneau, and R. Wilson, unpublished report) (adapted from Millers et al. 1991)

\begin{tabular}{lcc}
\hline Class code & Class range $(\%)$ & Accepted variability $(\%)$ \\
\hline 0 & 0 & $0-5$ \\
5 & $1-5$ & $0-15$ \\
10 & $6-15$ & $1-25$ \\
20 & $16-25$ & $6-35$ \\
30 & $26-35$ & $16-45$ \\
40 & $36-45$ & $26-55$ \\
50 & $46-55$ & $36-65$ \\
60 & $56-65$ & $46-75$ \\
70 & $66-75$ & $56-85$ \\
80 & $76-85$ & $66-95$ \\
90 & $86-95$ & $76-100$ \\
99 & $96-100$ & $86-100$ \\
\hline
\end{tabular}


shade, and health and vigor of butternut trees are believed to improve under sunlit conditions. However, more empirical evidence is needed to support the notion of beneficial impacts of overstory dominance vis-à-vis the disease, which we sought to determine in this work. We approached model fitting in two steps. First, we explored the empirical relationships of trunk canker and dieback percentage as a function of a single fixed effect (i.e., without adjusting for the other fixed effects) and after accounting for the location effect (henceforth referred to as the "simple mGLMM model"). The equations for the two responses are:

$$
\begin{gathered}
\text { Dieback: } y_{i j}=\gamma_{00}+\gamma_{10} x_{i j}+u_{0 j}+\varepsilon_{i j} \\
\text { Canker: } \operatorname{Logit}\left(\mu_{i j}\right)=\log \left[\mu_{i j} /\left(1-\mu_{i j}\right)\right]=\gamma_{00}+\gamma_{10} x_{i j}+u_{0 j}
\end{gathered}
$$

where index $i$ denotes the tree level and index $j$ denotes the location level; $y_{i j}$ is the arcsine square root-transformed percent dieback; in case of the dichotomous canker damage response variable, $\mu_{i j}$ represents the probability of presence of trunk canker; the parameters $\gamma_{00}$ and $u_{0 j}$ represent the intercept and deviation from the intercept (i.e., the random intercept term for location), respectively; $\gamma_{10}$ represents the slope coefficient; and $\varepsilon_{i j}$ represents the error term. The fixed effects $\left(x_{i j}\right)$ that were assessed separately for their association with disease outcomes included latitude, longitude, elevation, slope, tree phenotype, dominance, and DBH $(>7.5 \mathrm{~cm})$, which was centered at the mean.

We then studied the associations between the responses and all the fixed effects in a multiexplanatory variable setting, after accounting for the random location effect, to describe butternut canker epidemiology under the competing influences of different variables (henceforth referred to as the "multiple mGLMM model"). The equations for the multiple mGLMM models for the two responses are given by:

$$
\begin{gathered}
\text { Dieback: } y_{i j}=\gamma_{00}+\sum_{p=1}^{P} \gamma_{p 0} x_{p i j}+u_{0 j}+\varepsilon_{i j} \\
\text { Canker: } \operatorname{Logit}\left(\mu_{i j}\right)=\log \left(\frac{\mu_{i j}}{1-\mu_{i j}}\right)=\gamma_{00}+\sum_{p=1}^{P} \gamma_{p 0} x_{p i j}+u_{0 j}
\end{gathered}
$$

where the descriptions for $y_{i j}, \mu_{i j}, \gamma_{00}, u_{0 j}$, and $\varepsilon_{i j}$ are as previously described; and $\gamma_{p 0}$ are $P$ slope parameters $\left(\gamma_{10}, \ldots, \gamma_{p 0}\right)$ for the different explanatory variables. We did not consider interaction terms of tree attributes (namely, phenotype-DBH, dominance-DBH, and phenotype-dominance) in our final model because we did not find any evidence of significant associations of interaction effects with the responses. Three-way interactions were not considered either because they caused model convergence problems. Tests of hypotheses concerning the estimates of variability in mean responses between locations being significantly different from zero were performed using the Wald $Z$ test. Multivariate GLMM analyses were performed using the default variance-covariance structure (i.e., variance components) for the random intercept of location and the "unstructured" method for estimating the residual variances and covariances between the responses (i.e., canker damage and dieback) at the tree level within each location. For these analyses, survey data from 18 locations in Quebec ( $n=539$ trees), collected between the years 2007 and 2012, were used because phenotype data were unavailable for 2006.

Coarse-scale analysis of disease severity. We observed geographically divergent trends in dieback and trunk canker damage during the exploratory analysis of raw data, which suggested the possible influence of weather on disease dynamics of butternut canker at the landscape scale. We also studied the distribution patterns of butternut canker in Quebec prior to 2000 to examine the prevalence of the disease in the province before our surveys. Butternut canker was first reported in Quebec in 1990 from Waltham $\left(45.9167^{\circ},-76.8833^{\circ}\right)$ and Fort-Coulonge $\left(45.8167^{\circ},-76.6833^{\circ}\right.$ ) (Innes and Rainville 1996). Distribution records of butternut canker occurrences based on Quebec provincial surveys show presence of the disease in two plantations $\left(47.2942^{\circ},-70.1797^{\circ}\right.$ and $\left.48.1939^{\circ},-70.0214^{\circ}\right)$ further north of our surveyed sites in 1996 (Supplementary Fig. S3) (J. Bouchard, personal communication). The same surveys found butternut canker affecting trees outside of natural forests and plantations (e.g., trees occurring individually, such as in windbreaks, hedges, and so on) in 1998 $\left(46.5^{\circ},-72.25^{\circ}\right)$. These distribution data suggest that $O$. clavigignentijuglandacearum was distributed throughout the range of butternut in Quebec prior to 2000 and that the disease appears to have spread northeastward by at least $350 \mathrm{~km}$ in 8 years since the initial report in 1990 (spread rate of $44 \mathrm{~km} /$ year). Given the apparent ubiquity, rapid spread rate, divergent severity vertically and horizontally in space, and the opportunity for $O$. clavigignenti-juglandacearum to infect and colonize trees in the northern portion of the study area, we hypothesized that weather may have played a role in influencing the severity of the disease. Hence, we studied the associations between several meteorological variables with disease severity in order to identify key underlying variables that could be acting as potential drivers of the disease at a coarse scale.

Indices of disease severity. We overlaid a 1-by-1-km grid over the study area using ArcMap (v. 10.2; Quebec Lambert Conformal Conic Projection). This grid size was chosen (i) to address potential autocorrelation in the data (i.e., to assemble independent clusters of trees, given that the presumed airborne dispersal distance of $O$. clavigignentijuglandacearum conidia is believed to be about $1 \mathrm{~km}$ ) (Tisserat and Kuntz 1984) and (ii) to account for the different meteorological conditions experienced by trees that were sampled in a given location but that were scattered over large distances. Additionally, this grid size is common in studies of weather impacts on species distributions. Point data of tree coordinates from 24 different locations ( $n=746$ trees) were intersected with the $1-\mathrm{km}^{2}$ gridded surface in ArcMap, v. 10.2 such that each uniquely identified grid cell finally had tree-level attribute information attached to it. Only grid cells that contained at least five sampled trees were included in the analyses. We calculated a canker severity index $\left(S_{j}\right)$ per grid cell $j$ based on the percentage of trees under the different canker damage categories $i\left(P_{i}\right)$ and midpoint interval of the proportion of trunk canker damage on the stem $\left(X_{i}\right)$ (Table 1$)$ as:

$$
S_{j}=\sum_{i=0}^{4} P_{i} X_{i}
$$

In addition, we developed an overall disease index $\left(D I_{j}\right)$ for each grid cell $j$ that incorporated the median tree dieback (decimal value) within that grid cell as a weighting variable $\left(W_{j}\right)$ to the canker severity index $\left(S_{j}\right)$ as:

$$
D I_{j}=W_{j} * S_{j}=W_{j} * \sum_{i=0}^{4} P_{i} X_{i}
$$

where $i$ is the index that represents each of the trunk canker damage categories. Extensive dieback and high trunk canker damage in a grid cell would manifest themselves by a higher overall disease index value, and vice versa. We then studied the relationship between the canker severity index and the overall disease index with derived meteorological variables, as follows.

Tree-level coordinate information was used to generate daily weather data corresponding to two temporal windows (i.e., 3 or 5 years prior to and including the year of survey using BioSIM, v. 11) (Régnière 1996; Régnière and St-Amant 2007). Preliminary analyses showed that several weather variables within these two time periods were strongly associated with the two indices of the disease. We computed and averaged a total of 34 derived weather variables based on daily temperature in ${ }^{\circ} \mathrm{C}$, precipitation in centimeters, and water deficit in centimeters (i.e., potential evapotranspiration - precipitation $>0$, else water deficit $=0$ ) at the grid cell level using SAS, v. 9.3. Only weather variables were used as explanatory variables in the regression models because adding percent composition of butternut (by tree volume) per grid cell as a proxy for tree density did not significantly improve the model fit. The weather variables used in the analyses and averaged over a 3- or 5-year period included averages of daily mean, maximum, and minimum temperatures; mean annual total precipitation; mean annual total water deficit; average number of days with temperatures between 10 and $20^{\circ} \mathrm{C}$ per year; mean temperatures during 
winter (December to February), spring (March to May), summer (June to August), and fall (September to November); and mean total precipitation and mean total water deficit for the above four meteorological seasons. We included the number of days with optimal temperatures of 10 to $20^{\circ} \mathrm{C}$ per year as an explanatory variable in the analyses because results from a previous study suggested that temperatures falling within this range were optimal for spore viability (Tisserat and Kuntz 1983b). We initially studied the association of each of the weather variables singly with canker severity and overall disease indices, which were square-root transformed $[\sqrt{ }(x+0.5)]$ to reduce heterogeneity in the data (Zar 1999). We then sought to determine whether the predictive ability of the models could be improved by incorporating a reduced set of largely uncorrelated weather-based variables that were identified using variable clustering. In multiple regression analysis, using correlated explanatory variables results in unstable coefficient estimates and standard errors confounding inferences. We performed variable clustering using the VARCLUS procedure in SAS, v. 9.3. Briefly, the procedure iteratively assigns variables into clusters based on the amount of correlation (or similarity) among the variables until the clustering specifications are met (e.g., the specified amount of variation in the data is explained or the condition regarding the number of clusters is met). Then, cluster representatives (i.e., variables that are highly correlated with other variables in their own cluster but not as much correlated with variables in other clusters) are selected for use in models (Nelson 2001). We selected one variable from each of a maximum of five clusters that met the above criteria and that explained approximately $80 \%$ of the variation in the derived meteorological data. The variables selected included daily mean temperature (3 years), mean annual total precipitation (5 years), mean annual number of days with temperatures between 10 and $20^{\circ} \mathrm{C}$ ( 5 years), mean total spring precipitation ( 3 years), and mean total fall precipitation (5 years). We performed multiple regression analyses using the five selected weather variables as predictors of canker severity index and overall disease index using the REG procedure in SAS, v. 9.3. Variable selection was performed using the backward selection method. Model fit was assessed using the adjusted $R^{2}$ values.

\section{Results}

Tree-level analysis of disease severity using simple mGLMM models. The presence of trunk canker caused by O. clavigignenti-juglandacearum on butternut was negatively associated with latitude, indicating that trees in the northern portion of the study area have a lower probability of trunk canker damage than those in the southern portion (Table 3 ). Changes in percent dieback were not significantly associated with tree latitude $(P=0.2408)$. Probability of trunk canker damage was higher in trees occurring in the western portion of the study area than in those occurring in the eastern portion. No evidence of similar longitudinal trend in percent dieback was found in the study region (Table 3 ). These results show that there is a pronounced southwest to northeast (decreasing) gradient in trunk canker damage in the study region. Butternut dieback caused by $O$. clavigignenti-juglandacearum in Quebec did not show a similar two-dimensional spatial gradient. Probability of trunk canker damage and percent dieback were higher for trees occurring at higher elevations than for those occurring at lower elevations (Table 3). Trees occurring on flat lands were associated with a higher probability of trunk canker damage than those occurring on higher slopes, whereas percent dieback was not associated with slope.

When modeled singly (i.e., not considering the other variables), and conditional upon the effect of location, the probability of trunk canker did not differ between bark phenotypes (Table 3). However, trees with a smooth bark had significantly less dieback than trees with a deeply furrowed bark $(P=0.0242)$. Tree dominance was not associated with either trunk canker damage or dieback $(P \geq 0.05)$. Trunk canker damage was not associated with $\mathrm{DBH}$; that is, there is an equal probability of finding trunk cankers on smaller (or younger) trees than on larger (or older trees) trees (Table 3). In contrast, percent dieback was higher on large-diameter trees than on small-diameter trees $(P=0.0168$; Table 3$)$. Mean log odds of canker damage and mean percent dieback differed significantly between locations when the bivariate responses were modeled as functions of separate fixed effects, indicating that no single fixed effect by itself could explain the overall variation in responses among locations (Table 3 ).

Tree-level analysis of disease severity using multiple mGLMM models. In a multiple explanatory variable multivariate GLMM analysis using all the fixed effects in the model, latitude, longitude, elevation, slope, and DBH were significant predictors of trunk canker damage $(P<0.05)$, whereas phenotype and dominance were not $(P \geq 0.05)$ (Table 4$)$. The relationship between latitude and slope with respect to the probability of occurrence of trunk canker remained unchanged in the multiexplanatory variable setting when compared with the univariable setting (i.e., the probability of canker

Table 3. Tree-level multivariate generalized linear mixed models, in a single explanatory variable setting (equations 1 and 2), for assessing the presence of trunk canker damage and percent dieback of butternut (Juglans cinerea) caused by the fungal pathogen Ophiognomonia clavigignenti-juglandacearum in Quebec during the period 2007 to 2012

\begin{tabular}{|c|c|c|c|c|}
\hline \multirow[b]{2}{*}{ Effect } & \multirow[b]{2}{*}{ Disease measure } & \multicolumn{3}{|c|}{ Estimates $(\mathrm{SE})^{\mathbf{a}}$} \\
\hline & & Intercept & Parameter (slope) & Random intercept variance $^{b}$ \\
\hline \multicolumn{5}{|l|}{ Geographic or topographic attributes } \\
\hline \multirow[t]{2}{*}{ Latitude } & Canker & $2.8026(0.2533)^{* * *}$ & $-1.8709(0.2306)^{* * *}$ & $0.0155(0.0062)^{* *}$ \\
\hline & Dieback & $0.4866(0.0607)^{* * *}$ & $-0.0737(0.0628) \mathrm{ns}$ & $\ldots$ \\
\hline \multirow[t]{2}{*}{ Longitude } & Canker & $3.1929(0.3422)^{* * *}$ & $-0.9223(0.1353)^{* * *}$ & $0.0173(0.0069)^{* *}$ \\
\hline & Dieback & $0.4396(0.0810)^{* * *}$ & $-0.0066(0.0360) \mathrm{ns}$ & $\ldots$ \\
\hline \multirow[t]{2}{*}{ Elevation } & Canker & $0.9038(0.1422)^{* * *}$ & $0.0031(0.0015)^{*}$ & $0.0056(0.0032) *$ \\
\hline & Dieback & $0.3426(0.0294)^{* * *}$ & $0.0013(0.0003)^{* * *}$ & $\ldots$ \\
\hline \multirow[t]{2}{*}{ Slope } & Canker & $1.3422(0.1208)^{* * *}$ & $-0.0551(0.0125)^{* * *}$ & $0.0175(0.0070)^{* *}$ \\
\hline & Dieback & $0.4169(0.0353)^{* * *}$ & $0.0019(0.0023) \mathrm{ns}$ & $\ldots$ \\
\hline \multicolumn{5}{|l|}{ Tree attributes $^{c}$} \\
\hline \multirow[t]{2}{*}{ Phenotype (smooth versus coarse) } & Canker & $1.1395(0.2013)^{* * *}$ & $-0.0335(0.2299) \mathrm{ns}$ & $0.0163(0.0064)^{* *}$ \\
\hline & Dieback & $0.4756(0.0395)^{* * *}$ & $-0.0627(0.0278)^{*}$ & $\ldots$ \\
\hline Dominance (O/D versus I/S) & Canker & $0.9884(0.3700)^{* *}$ & $0.0563(0.3983) \mathrm{ns}$ & $0.0165(0.0064)^{* *}$ \\
\hline Dominance $(\mathrm{C}$ versus $\mathrm{I} / \mathrm{S})$ & $\ldots$ & $\ldots$ & $0.1994(0.3955) \mathrm{ns}$ & $\ldots$ \\
\hline Dominance (O/D versus I/S) & Dieback & $0.4607(0.0536)^{* * *}$ & $-0.0481(0.0485) \mathrm{ns}$ & $\ldots$ \\
\hline Dominance $(\mathrm{C}$ versus $\mathrm{I} / \mathrm{S})$ & $\ldots$ & $\ldots$ & $-0.0286(0.0463) \mathrm{ns}$ & $\ldots$ \\
\hline \multirow[t]{2}{*}{ Diameter at breast height } & Canker & $1.1174(0.1049) * * *$ & $0.0130(0.0074) \mathrm{ns}$ & $0.0173(0.0068)^{* *}$ \\
\hline & Dieback & $0.4235(0.0335)^{* * *}$ & $0.0021(0.0009)^{*}$ & $\ldots$ \\
\hline
\end{tabular}

\footnotetext{
a Significance of parameter estimates: $* * *=P<0.001, * *=0.001 \leq P<0.01, *=0.01 \leq P<0.05$, and $\mathrm{ns}=P \geq 0.05$. SE $=$ standard error.

${ }^{\mathrm{b}}$ Random intercept variance represents the variance estimate between locations with respect to the bivariate responses.

${ }^{\mathrm{c}}$ Binary phenotype categories: smooth $(=1)=$ smooth-bark phenotype and coarse $(=0)=$ coarse-bark phenotype; and dominance categories: $\mathrm{O} / \mathrm{D}=$ open or dominant, $\mathrm{I} / \mathrm{S}=$ intermediate or suppressed (reference), and $\mathrm{C}=$ codominant.
} 
presence was negatively related to latitude and slope). At a given tree latitude and slope, the probability of trunk canker presence on butternut trees (i) decreased from east to west within the study area, (ii) decreased with increasing elevation, and (iii) increased with increasing DBH (Table 4).

For the dieback multivariable model analysis, percent dieback increased with increases in elevation and DBH (Table 4). For trees located at the same elevation and having the same DBH, results show that open or dominant trees have a significantly smaller percent dieback than intermediate or suppressed trees. However, codominant trees and intermediate or suppressed trees did not differ in the amount of dieback (Table 4). Mean log odds of canker damage and mean percent dieback did not differ between locations $(P=0.0685)$, indicating that the multivariable model sufficiently accounted for all the variance in the response data at the location level (Table 4). Variancecovariance estimates of residuals for the GLMM show that dieback and canker damage did not covary in our study area (Supplementary Table S1).

Coarse-scale analysis of disease severity: Associations of meteorological variables with canker severity index and overall disease index. Thirty-four meteorological variables over two temporal windows ( 3 and 5 years) were used in simple regression analyses (i.e., individual variables separately) to assess their relationship with canker severity index and overall disease index. Only 9 of 34 meteorological variables over both temporal windows showed significant positive relationships with canker severity index $(P<0.05)$. These included daily mean temperature, mean daily maximum temperature, mean annual total water deficit, mean winter temperature, mean spring temperature, mean summer temperature, mean fall temperature, mean total spring water deficit, and mean total summer water deficit (Table 5). Mean daily maximum temperature over 3 years had the strongest positive association with canker severity index (adjusted [adj.] $R^{2}=0.47$ ). Regardless of the time periods ( 3 or 5 years) of calculation of weather variables, positive relationships were

Table 4. Tree-level multivariate generalized linear mixed models, in a multiexplanatory variable setting (equations 3 and 4 ), for assessing the presence of trunk canker damage and percent dieback of butternut (Juglans cinerea) caused by the fungal pathogen Ophiognomonia clavigignenti-juglandacearum in Quebec during the period 2007 to 2012

\begin{tabular}{lc}
\hline Effect, disease measure $^{\mathbf{a}}$ & Estimate (SE) $^{\mathbf{b}}$ \\
\hline Fixed effects & \\
Canker & \\
Intercept & $1.8315(0.5547)^{* *}$ \\
Latitude & $-4.9114(1.0196)^{* * *}$ \\
Longitude & $1.6981(0.5100)^{* * *}$ \\
Elevation & $-0.0091(0.0033)^{* *}$ \\
Slope & $-0.0438(0.0140)^{* *}$ \\
Phenotype (smooth versus coarse) & $0.4923(0.2849) \mathrm{ns}$ \\
Dominance (O/D versus I/S) & $0.3767(0.5018) \mathrm{ns}$ \\
Dominance (C versus I/S) & $0.5014(0.4628) \mathrm{ns}$ \\
Diameter at breast height & $0.0278(0.0100)^{* *}$ \\
Dieback & \\
Intercept & $0.4587(0.0732)^{* * *}$ \\
Latitude & $-0.0562(0.1267) \mathrm{ns}$ \\
Longitude & $0.0255(0.0680) \mathrm{ns}$ \\
Elevation & $0.0012(0.0004)^{* *}$ \\
Slope & $-0.0008(0.0021) \mathrm{ns}$ \\
Phenotype (smooth versus coarse) & $-0.0399(0.0292) \mathrm{ns}$ \\
Dominance (O/D versus I/S) & $-0.1232(0.0519)^{*}$ \\
Dominance (C versus I/S) & $-0.0657(0.0470) \mathrm{ns}$ \\
Diameter at breast height & $0.0029(0.0010)^{* *}$ \\
Random effect (location) & \\
Intercept variance & $0.0060(0.0040) \mathrm{ns}$ \\
\hline
\end{tabular}

a Binary phenotype categories: smooth $(=1)=$ smooth-bark phenotype and coarse $(=0)=$ coarse-bark phenotype; and dominance categories: $\mathrm{O} / \mathrm{D}=$ open or dominant, $\mathrm{I} / \mathrm{S}=$ intermediate or suppressed (reference), and $\mathrm{C}=$ codominant.

b Significance of parameter estimates: $* * *=P<0.001, * *=0.001 \leq P<$ $0.01, *=0.01 \leq P<0.05$, and $\mathrm{ns}=P \geq 0.05$. $\mathrm{SE}=$ standard error. observed for mean daily maximum temperature, mean annual total precipitation, mean spring temperature (3 years), mean total summer precipitation, and mean total spring water deficit with respect to overall disease index. Finally, mean daily maximum temperature, mean spring temperature, and mean total spring water deficit had significant positive relationships with both canker severity index and disease index (Table 5).

A multiple regression model for canker severity index using a reduced set of largely uncorrelated variables did not explain as much variation in the data (adj. $R^{2}=0.39$, Table 6 ) as mean daily maximum temperature over 3 years $\left(\operatorname{adj} . R^{2}=0.47\right.$, Table 5$)$. Keeping the other covariates in the model constant, increases in daily mean temperature (3 years) increased the canker severity index, whereas increases in the mean annual number of days with temperatures between 10 and $20^{\circ} \mathrm{C}$ had the opposite effect (Table 6).

For overall disease index, using multiple predictors improved the fit of the model (adj. $\left.R^{2}=0.28\right)$ compared with any of the models using a single explanatory weather variable (Tables 5 and 6). Keeping the other covariates in the multiple regression model constant, increases in overall disease index values were associated with (i) increases in mean daily temperature (3 years), (ii) increases in mean annual precipitation (5 years), and (iii) decreases in mean annual number of days with temperatures between 10 and $20^{\circ} \mathrm{C}$ ( 5 years) (Table 6).

\section{Discussion}

Results of our analyses provide significant insights into relationships between butternut canker disease occurrence and different cross-scale factors. To summarize, our study (i) provides the first evidence of the existence of notable spatial trends in trunk canker severity and dieback in Quebec; (ii) establishes an association between topographic features (elevation and slope) and butternut canker disease severity; (iii) does not conclusively show that coarse-bark phenotypes are less susceptible to $O$. clavigignenti-juglandacearum than smooth-bark phenotypes, as is generally believed; (iv) supports the hypothesis that open or dominant trees have less dieback than intermediate or suppressed trees, after controlling for other key factors; and (v) proves that weather plays an important role in the spatial dynamics of the disease.

Butternut canker showed distinct geographical patterns in our study area. Trunk canker damage was noticeably less significant in the northern portion of the study area than in the southern portion. Dieback had more of an elevational gradient than a latitudinal gradient. There are several possibilities that explain higher canker severity in the south of the study area. First, trees in the southern part of the range were infected earlier and, thus, were exposed to O. clavigignenti-juglandacearum for a longer period of time than the butternut populations in the north of the study area. Second, the southern portion of the butternut range in Quebec has a higher overall inoculum load of $O$. clavigignenti-juglandacearum, possibly due to greater tree populations, than the northern portion, where populations may be more fragmented. Third, butternut populations may show genetic differences in resistance to the disease. Finally, conducive weather could have favored the epidemiology of the disease in the southern portion of the study area whereas unfavorable weather conditions could have limited the impact of $O$. clavigignentijuglandacearum as butternut approaches its northern range limit. Unfortunately, limited comprehensive ground surveys and spore capture data covering multiple years exist to pinpoint the role of time since infection in disease severity and to estimate the rate of spread of the disease across the landscape. Nevertheless, provincial data indicate that butternut canker spread rapidly in Quebec before the year 2000 , which suggests the possibility that all of our studied sites were exposed to $O$. clavigignenti-juglandacearum for a duration sufficient for disease progression. Butternut populations in Quebec are less likely to present different levels of disease resistance because they have been shown to have low genetic diversity (Morin et al. 2000). In fact, populations of butternut in the northern range of the species in North America in general have lower genetic diversity than more southern populations (Hoban et al. 2010). It should be noted, 
however, that multiple local factors such as habitat type and land-use history (Hoban et al. 2014), and even the disease itself, may dynamically shape the spatial genetic structure of butternut that could further induce variability in disease severity patterns.

Contrasting spatial patterns in trunk canker damage (by latitude) and dieback (by elevation) in this study are difficult to explain but may possibly be attributed to trends in temperature and precipitation, respectively. For example, we found that variations in latitude and longitude strongly influenced temperature and water deficit variables, whereas variations in elevation similarly influenced precipitation variables (data not shown). Therefore, one explanation for greater canker damage at southern latitudes could be that butternut trees are more water-stressed due to relatively higher temperatures than those at northern latitudes. We suspect that similar weather factors might be one of the drivers of variability in butternut canker in the United States, where a recent study (Brosi 2010) found a southto-north declining trend in overall canker rating. In the case of dieback in our study area, foggy conditions, high humidity, and more precipitation at higher elevations could increase the viability and spread of spores in the canopy and, thus, may have contributed to higher dieback. In addition, stronger winds at higher elevations may potentially contribute to greater dieback via spread of spores. Therefore, weather appears to be a strong factor driving the spatial epidemiology of butternut canker.

Butternut trees with deeply furrowed, dark-gray bark are believed to be putatively resistant to $O$. clavigignenti-juglandacearum (Ostry and Woeste 2004; Ostry et al. 2003). However, the results of our analyses do not provide convincing statistical evidence in support of this hypothesis. Deeply furrowed, dark-gray phenotypes may not necessarily be immune to butternut canker although, compared with smooth, light-gray phenotypes, they are less likely to be diseased or dead (Boraks and Broders 2014; LaBonte 2013; Ostry et al. 2003), possibly because they can tolerate the disease much better than smooth-bark phenotypes or because they present physical

Table 5. Associations of canker severity index and overall disease index (equations 5 and 6) of butternut canker, caused by the fungal pathogen Ophiognomonia clavigignenti-juglandacearum, with weather-related variables calculated over a 3-year or 5-year period in Quebec ${ }^{\mathrm{a}}$

\begin{tabular}{|c|c|c|c|c|}
\hline \multirow[b]{2}{*}{ Meteorological variable } & \multicolumn{2}{|c|}{ Canker severity index ${ }^{b}$} & \multicolumn{2}{|c|}{ Overall disease index ${ }^{b}$} \\
\hline & 3-year & 5-year & 3-year & 5-year \\
\hline Daily mean temperature $\left({ }^{\circ} \mathrm{C}\right)$ & $1.2861 \pm 0.3318(0.25)$ & $0.9548 \pm 0.3291(0.15)$ & $0.2522 \pm 0.1380(0.05)$ & $0.2424 \pm 0.1282(0.06)$ \\
\hline Mean daily maximum temperature $\left({ }^{\circ} \mathrm{C}\right)$ & $1.7486 \pm 0.2847(0.47)$ & $1.8586 \pm 0.3165(0.44)$ & $0.3347 \pm 0.1369(0.11)$ & $0.4102 \pm 0.1457(0.15)$ \\
\hline Mean daily minimum temperature $\left({ }^{\circ} \mathrm{C}\right)$ & $0.4418 \pm 0.2705(0.04)$ & $0.2622 \pm 0.2417(0.00)$ & $0.0769 \pm 0.1027(-0.01)$ & $0.0759 \pm 0.0904(-0.01)$ \\
\hline Mean annual total precipitation $(\mathrm{cm})$ & $0.0088 \pm 0.0336(-0.02)$ & $0.0160 \pm 0.0290(-0.02)$ & $0.0258 \pm 0.0119(0.08)$ & $0.0272 \pm 0.0100(0.14)$ \\
\hline Mean annual total water deficit $(\mathrm{cm})$ & $0.5230 \pm 0.1388(0.24)$ & $0.4005 \pm 0.1384(0.15)$ & $0.1024 \pm 0.0574(0.05)$ & $0.1009 \pm 0.0540(0.06)$ \\
\hline $\begin{array}{l}\text { Mean number of days with temperatures of } 10 \\
\text { to } 20^{\circ} \mathrm{C}\end{array}$ & $-0.1082 \pm 0.0632(0.04)$ & $-0.0876 \pm 0.0595(0.03)$ & $-0.0344 \pm 0.0241(0.03)$ & $-0.0181 \pm 0.0228(-0.01)$ \\
\hline $\begin{array}{l}\text { Mean winter (December-February) } \\
\text { temperature }\left({ }^{\circ} \mathrm{C}\right)\end{array}$ & $0.6928 \pm 0.2515(0.14)$ & $0.5702 \pm 0.2512(0.09)$ & $0.1515 \pm 0.0986(0.03)$ & $0.1561 \pm 0.0957(0.04)$ \\
\hline Mean spring (March-May) temperature $\left({ }^{\circ} \mathrm{C}\right)$ & $1.2814 \pm 0.2623(0.35)$ & $0.8426 \pm 0.2606(0.18)$ & $0.3031 \pm 0.1124(0.13)$ & $0.2535 \pm 0.1006(0.12)$ \\
\hline Mean summer (June-August) temperature $\left({ }^{\circ} \mathrm{C}\right)$ & $1.2429 \pm 0.3588(0.21)$ & $1.0683 \pm 0.3677(0.15)$ & $0.2030 \pm 0.1483(0.02)$ & $0.1946 \pm 0.1465(0.02)$ \\
\hline $\begin{array}{l}\text { Mean fall (September-November) } \\
\text { temperature }\left({ }^{\circ} \mathrm{C}\right)\end{array}$ & $1.1177 \pm 0.4061(0.14)$ & $0.8506 \pm 0.3997(0.08)$ & $0.1373 \pm 0.1623(-0.01)$ & $0.1918 \pm 0.1531(0.01)$ \\
\hline Mean total winter precipitation $(\mathrm{cm})$ & $-0.0046 \pm 0.0730(-0.02)$ & $-0.0161 \pm 0.0686(-0.02)$ & $0.0321 \pm 0.0271(0.01)$ & $0.0439 \pm 0.0252(0.05)$ \\
\hline Mean total spring precipitation (cm) & $0.0496 \pm 0.1014(-0.02)$ & $0.1567 \pm 0.1010(0.03)$ & $0.0100 \pm 0.0376(-0.02)$ & $0.0625 \pm 0.0372(0.04)$ \\
\hline Mean total summer precipitation $(\mathrm{cm})$ & $-0.0028 \pm 0.0650(-0.02)$ & $0.0277 \pm 0.0574(-0.02)$ & $0.0584 \pm 0.0226(0.12)$ & $0.0455 \pm 0.0202(0.09)$ \\
\hline Mean total fall precipitation $(\mathrm{cm})$ & $0.0243 \pm 0.0738(-0.02)$ & $-0.0043 \pm 0.0899(-0.02)$ & $0.0130 \pm 0.0276(-0.02)$ & $0.0269 \pm 0.0330(-0.01)$ \\
\hline Mean total spring water deficit $(\mathrm{cm})$ & $1.2604 \pm 0.3326(0.24)$ & $0.8511 \pm 0.3163(0.13)$ & $0.3746 \pm 0.1304(0.15)$ & $0.3059 \pm 0.1181(0.12)$ \\
\hline Mean total summer water deficit $(\mathrm{cm})$ & $1.0981 \pm 0.3271(0.20)$ & $0.9465 \pm 0.3328(0.15)$ & $0.1673 \pm 0.1351(0.01)$ & $0.1517 \pm 0.1331(0.01)$ \\
\hline Mean total fall water deficit $(\mathrm{cm})$ & $0.9968 \pm 0.4947(0.07)$ & $0.8414 \pm 0.5126(0.04)$ & $0.0645 \pm 0.1918(-0.02)$ & $0.1838 \pm 0.1942(0.00)$ \\
\hline
\end{tabular}

${ }^{a}$ Canker severity index per $1-\mathrm{km}^{2}$ grid cell is the sum of the product of the percentage of trees under different canker damage categories and midpoint interval of the proportion of trunk canker damage. Overall disease index is the product of median tree dieback (decimal) per 1-km² grid cell and canker severity index.

${ }^{\mathrm{b}}$ For canker severity index, $n=43$. One extreme outlier was removed when modeling the overall disease index $(n=42)$. Parameter estimates \pm standard error (adjusted $\left.R^{2}\right)$ in bold indicate significance $(P<0.05)$.

Table 6. Predictive multiple regression models for canker severity index and overall disease index (equations 5 and 6) for butternut canker disease caused by the fungal pathogen Ophiognomonia clavigignenti-juglandacearum in Quebec ${ }^{\mathrm{a}}$

\begin{tabular}{|c|c|c|c|c|c|c|}
\hline Variable $^{\mathrm{b}}$ & Estimate $\pm \mathbf{S E}^{\mathbf{c}}$ & $t$ Value & $\operatorname{Pr}>|t|$ & $\mathbf{V I F}^{\mathbf{d}}$ & $F$ value $^{\mathrm{e}}$ & Adjusted $R^{2}$ \\
\hline \multicolumn{7}{|l|}{ Canker severity index } \\
\hline Intercept & $-3.4931 \pm 1.8238$ & -1.92 & 0.0626 & 0.0 & $14.51 * * *$ & 0.39 \\
\hline Daily mean temperature $\left({ }^{\circ} \mathrm{C}\right), 3$-year & $1.5784 \pm 0.3123$ & 5.05 & $<0.0001$ & 1.1 & $\ldots$ & $\ldots$ \\
\hline $\begin{array}{l}\text { Mean number of days with temperatures of } \\
10 \text { to } 20^{\circ} \mathrm{C}, 5 \text {-year }\end{array}$ & $-0.1592 \pm 0.0491$ & -3.24 & 0.0024 & 1.1 & $\ldots$ & $\ldots$ \\
\hline \multicolumn{7}{|l|}{ Overall disease index } \\
\hline Intercept & $-3.3722 \pm 1.2419$ & -2.72 & 0.0099 & 0.0 & $6.40 * *$ & 0.28 \\
\hline Daily mean temperature $\left({ }^{\circ} \mathrm{C}\right), 3$-year & $0.3329 \pm 0.1260$ & 2.64 & 0.0119 & 1.1 & $\ldots$ & $\ldots$ \\
\hline Mean annual precipitation $(\mathrm{cm}), 5$-year & $0.0329 \pm 0.0095$ & 3.48 & 0.0013 & 1.1 & $\ldots$ & $\ldots$ \\
\hline $\begin{array}{l}\text { Mean number of days with temperatures of } \\
10 \text { to } 20^{\circ} \mathrm{C}, 5 \text {-year }\end{array}$ & $-0.0528 \pm 0.0209$ & -2.52 & 0.0159 & 1.2 & $\ldots$ & $\cdots$ \\
\hline
\end{tabular}

${ }^{\text {a }}$ Canker severity index per $1-\mathrm{km}^{2}$ grid cell is the sum of the product of the percentage of trees under different canker damage categories and midpoint interval of the proportion of trunk canker damage. Overall disease index is the product of median tree dieback (decimal) per 1-km ${ }^{2}$ grid cell and canker severity index.

${ }^{\mathrm{b}}$ For canker severity index, $n=43$. One extreme outlier was removed when modeling the overall disease index $(n=42)$.

${ }^{\mathrm{c}} \mathrm{SE}=$ standard error.

d Variance inflation factor (values around 1 indicate noncorrelated explanatory variables).

${ }^{\mathrm{e}}$ Asterisks indicate significance of the models: ${ }^{* * *}=P<0.001$ and ${ }^{* *}=0.001 \leq P<0.01$. 
barriers to pathogen entry. For example, heartnut and Japanese walnut, which are both quite resistant to $O$. clavigignenti-juglandacearum, have thicker periderms than susceptible species such as butternut (Nair 1999), and such thick periderms might limit bark infection. Research is needed to examine whether any such anatomical differences exist between the two bark phenotypes in butternut. Our findings are not consistent with some previous studies that show that the darkbark phenotype is associated with lower levels of butternut canker (Brosi 2010; LaBonte 2013; Ross-Davis et al. 2008). Observations from a smaller number of locations may not apply range-wide given the variations in environmental conditions between locations across the range of butternut (Brosi 2010; LaBonte 2013). Boraks and Broders (2014) found significant differences in percent canker girdling but not in the number of trunk cankers between the smoothbark and deeply furrowed phenotypes. However, they suggest that tree phenotype may be unrelated to canker resistance when DBH is taken into consideration. Therefore, it appears that the relationship between tree phenotype and disease severity is more complex and requires that other factors be taken into consideration, as we have done in this study.

Uncertainties and biases inherent in our study may have influenced the phenotype-butternut canker relationships. For example, it is possible that bias due to human error during the data collection phase (e.g., visual phenotypic classification) could have confounded the results. Another source of uncertainty is the occurrence of butternut hybrids, the extent of which is unknown in most of our study area, which occur admixed naturally in northeastern hardwood forests and are often indistinguishable from pure butternut trees (Hoban et al. 2009); butternut hybrids are more resistant to $O$. clavigignenti-juglandacearum than pure butternut trees (Boraks and Broders 2014; McKenna et al. 2011). However, plant hardiness classification suggests that climatic conditions prevailing in most of Quebec, with the exception of the southwestern part of the province and certain riparian areas in the north, are prohibitive to the growth of heartnut and eastern black walnut (CPNCQ 2014; McKenney et al. 2014). A recent analysis of butternut trees from StAugustin, Quebec, occurring at the northernmost limit of butternut range, showed that they were pure butternut trees (D. Rioux, unpublished data). Due to the limited number of locations where heartnut is planted in Quebec (CPNCQ 2014), the hybridization potential of butternut with heartnut in this region appears minimal. Nonetheless, a combination of marker-assisted tree identification (Hoban et al. 2008; McCleary et al. 2009), a greater understanding of the genetic basis for canker resistance in deeply furrowed phenotypes (Michler et al. 2006; Ostry and Woeste 2004), and spatiotemporal epidemiological data of the disease will be highly useful in systematically examining the role of phenotype in butternut canker resistance.

Butternut is an early-successional, shade-intolerant species that thrives in the overstory and in open areas (Ostry and Woeste 2004; Woeste et al. 2009). Not surprisingly, canopy position is an important determinant of dieback caused by $O$. clavigignenti-juglandacearum. Our final model indicates that open or overstory butternut trees that are similar in size and growing at the same elevation as understory trees are likely to experience less dieback than trees in the understory. Canopy position was not related to the presence or absence of trunk canker damage. Overall, large-diameter trees were generally more affected by the disease than small-diameter trees, possibly because larger trees could have been affected earlier or were potentially stressed due to specific habitat features (e.g., competition, root disease, and so on). Additionally, exploratory analyses did not reveal any significant two-way relationships between canopy position and DBH (or bark phenotype) with respect to disease outcomes. Based on the above observations, it appears that creating canopy gaps (Woeste et al. 2009) may not directly reduce the impact of the disease over the long term.

This is the first study to highlight the importance of weather as a key driving factor of overall spatial dynamics of butternut canker at the landscape scale. Our results suggest that increasing temperatures (e.g., mean daily maximum temperature), precipitation, and water deficit conditions worsen the severity of the disease across the landscape. Weather impacts on butternut canker may occur in two ways: first, by directly influencing the release, germination, viability, longevity, and dispersal of $O$. clavigignenti-juglandacearum spores; and second, by affecting the host tree. For instance, temperature and RH influence the viability and longevity of $O$. clavigignenti-juglandacearum spores (Moore and Ostry 2015; Tisserat and Kuntz 1983b). Viability and longevity of $O$. clavigignenti-juglandacearum spores were reported to be higher at 13 than at $25^{\circ} \mathrm{C}$ (Tisserat and Kuntz 1983b). Rainfall appears to be essential for spore release or dissemination, and short-range dispersal (approximately $40 \mathrm{~m}$ ) of $O$. clavigignenti-juglandacearum spores occurs when rain drops impact the exposed fruiting bodies on host branches (Nicholls 1979; Tisserat and Kuntz 1983a). Clark et al. (2008) found that butternut growth was positively correlated with April temperature and precipitation in June and July and negatively correlated with summer drought. However, how weather-induced changes in butternut physiology and growth influence disease severity is unknown. One unexpected finding in our study was that increases in the number of days with presumably optimal temperatures of 10 to $20^{\circ} \mathrm{C}$ was negatively associated with canker severity index and overall disease index, which is contrary to what previous laboratory-based studies suggest (Moore and Ostry 2015; Tisserat and Kuntz 1983b). It is possible that the optimal temperature range for the pathogen is different in the field from what has been observed in the laboratory. This explanation is consistent with the positive relationships observed between the temperature terms and the severity indices. Future studies will need to investigate the interactions between host tree, disease, and weather for an improved understanding of the spatiotemporal epidemiology of butternut canker.

Butternut canker is perhaps one of the classic cases of a forest disease posing an existential threat to the affected tree species. It is clear from our study, and from previous studies reporting butternut canker in the United States (Anderson and LaMadeleine 1978; Brosi 2010), that butternut may eventually be on the path to extinction due to this disease. Furthermore, the cascading effects of land-use changes, lack of regeneration in affected habitats, and short-distance dispersal of seed, which in turn may get infected by $O$. clavigignenti-juglandacearum (Innes 1998), further contribute to endangering the existence of butternut trees across the landscape in the future. Realizing the threats to butternut survival, researchers over the past two decades have paid substantial attention to investigating strategies aimed at saving butternut. For example, previous research efforts have focused on the identification of putatively resistant butternut trees, the propagation of resistant butternut scionwood via grafting on other Juglans spp., in vitro propagation through somatic embryogenesis, screening for disease resistance, and the identification of environmentally suitable habitats for butternut restoration (Ostry and Woeste 2004; Pijut 1993; Schlarbaum et al. 2004; Thompson et al. 2006; Van Sambeek et al. 2003). Continuing research on these very promising strategies will be crucial in stemming the impending decline of butternut in North America. Finally, future planning should take the effects of climate change into consideration; for example, when deploying potentially resistant trees within or beyond the current range of butternut.

\section{Acknowledgments}

This work would not have been possible without assistance and collaboration from numerous individuals and organizations, for which we are very grateful. They include C. Lajeunesse (Agence forestière de la Montérégie), M. Saint-Germain (Université du Québec à Montréal), L. Monette (Centre d'interprétation du milieu écologique du Haut-Richelieu), A. Blais and A. Lachance (Conseil régional de l'environnement du Centre-du-Québec), B. Roberge and L. Robillard (Environment Canada), J. Bouliane (Forêt Montmorency, Université Laval), N. Nadeau-Thibodeau (Université Laval), and I. Beaudoin-Roy (Commission de la capitale nationale du Québec, Parc de la Gatineau). We thank J. Bouchard (Ministère des Forêts, de la Faune et des Parcs du Québec) for providing the provincial annual survey data for butternut canker; J. Tao and K. Kiernan (SAS Institute, Cary, NC) for their clarifications regarding the GLIMMIX procedure; Laurentian Forestry Centre technicians M. Blais, C. Bourdon, J. Thibault, G. Bélanger, and B. Filion for their assistance; M. Cruickshank (Canadian Forest Service) and two anonymous reviewers for helpful comments and suggestions that greatly improved the quality of this article; and I. Lamarre (Canadian Forest Service) for proofreading the article.

\section{Literature Cited}

Anderson, R. L., and LaMadeleine, L. A. 1978. The distribution of butternut decline in the eastern United States. Forest Insect and Disease Management 
Survey Report S-3-78. U.S. Dep. Agric. For. Serv., Northeastern Area State and Private Forestry, Broomall, PA.

Boraks, A., and Broders, K. D. 2014. Butternut (Juglans cinerea) health, hybridization, and recruitment in the northeastern United States. Can. J. For. Res. 44:1244-1252.

Broders, K., Boraks, A., Barbison, L., Brown, J., and Boland, G. J. 2015. Recent insights into the pandemic disease butternut canker caused by the invasive pathogen Ophiognomonia clavigignenti-juglandacearum. For. Pathol. 45:1-8.

Broders, K. D., and Boland, G. J. 2010. Molecular diagnostic assay for detection of the butternut canker pathogen Sirococcus clavigignenti-juglandacearum. Plant Dis. 94:952-958.

Broders, K. D., and Boland, G. J. 2011. Reclassification of the butternut canker fungus, Sirococcus clavigignenti-juglandacearum, into the genus Ophiognomonia. Fungal Biol. 115:70-79.

Broders, K. D., Boraks, A., Sanchez, A. M., and Boland, G. J. 2012. Population structure of the butternut canker fungus, Ophiognomonia clavigignentijuglandacearum, in North American forests. Ecol. Evol. 2:2114-2127.

Brosi, S. L. 2010. Steps toward butternut (Juglans cinerea L.) restoration. Ph.D. thesis, University of Tennessee, Knoxville.

Clark, S. L., Brosi, S. L., Schlarbaum, S. E., and Grissino-Mayer, H. D. 2008. Dendrochronology of two butternut (Juglans cinerea) populations in the southeastern United States. For. Ecol. Manage. 255:1772-1780.

CPNCQ. 2014. Technical Fact Sheets of Trees Producing Edible Nuts and Acorns, 2nd ed. Club des producteurs de noix comestibles du Québec (CPNCQ), NotreDame-de-Ham, QC, Canada.

Davis, C. N., Myren, D. T., and Czerwinski, E. J. 1992. First report of butternut canker in Ontario. Plant Dis. 76:972.

Farlee, L., Woeste, K., Ostry, M., McKenna, J., and Weeks, S. 2010a. Conservation and Management of Butternut Trees. Purdue Univ. Coop. Ext. Serv. FNR-421-W. Purdue University Forestry and Natural Resources, West Lafayette, IN.

Farlee, L., Woeste, K., Ostry, M., McKenna, J., and Weeks, S. 2010b. Identification of Butternuts and Butternut Hybrids. Purdue Univ. Coop. Ext. Serv. FNR-420-W. Purdue University Forestry and Natural Resources, West Lafayette, IN.

Farrar, J. L. 1995. Trees in Canada. Fitzhenry \& Whiteside Limited, Markham, ON, Canada, and Natural Resources Canada, Canadian Forest Service, Ottawa, ON, Canada.

Fleguel, V. R. 1996. A literature review of butternut and the butternut canker. In: Eastern Ontario Model For. Inf. Rep. No. 20. Eastern Ontario Model Forest, Kemptville, ON, Canada.

Furnier, G. R., Stolz, A. M., Mustaphi, R. M., and Ostry, M. E. 1999. Genetic evidence that butternut canker was recently introduced into North America. Can. J. Bot. 77:783-785.

Goldstein, H. 1995. Multilevel Statistical Models, 2nd ed. Arnold Publishers Ltd, London.

Halik, S., and Bergdahl, D. R. 2002. Potential beetle vectors of Sirococcus clavigignenti-juglandacearum on butternut. Plant Dis. 86:521-527.

Harrison, K. J., Hurley, J. E., and Ostry, M. E. 1998. First report of butternut canker caused by Sirococcus clavigignenti-juglandacearum in New Brunswick, Canada. Plant Dis. 82:1282.

Hoban, S., Anderson, R., McCleary, T., Schlarbaum, S., and Romero-Severson, J. 2008. Thirteen nuclear microsatellite loci for butternut (Juglans cinerea L.). Mol. Ecol. Resour. 8:643-646.

Hoban, S. M., Borkowski, D. S., Brosi, S. L., McCleary, T. S., Thompson, L. M., McLachlan, J. S., Pereira, M. A., Schlarbaum, S. E., and Romero-Severson, J. 2010. Range-wide distribution of genetic diversity in the North American tree Juglans cinerea: A product of range shifts, not ecological marginality or recent population decline. Mol. Ecol. 19:4876-4891.

Hoban, S. M., McCleary, T. S., Schlarbaum, S. E., and Romero-Severson, J. 2009. Geographically extensive hybridization between the forest trees American butternut and Japanese walnut. Biol. Lett. 5:324-327.

Hoban, S. M., McCleary, T. S., Schlarbaum, S. E., and Romero-Severson, J. 2014. Spatial genetic structure in 21 populations of butternut, a temperate forest tree (Juglans cinerea L.), is correlated to spatial arrangement, habitat, and land-use history. For. Ecol. Manage. 314:50-58.

Innes, L. 1998. Sirococcus clavigignenti-juglandacearum on butternut and black walnut fruit. Pages 129-132 in: Foliage, Shoot and Stem Diseases of Trees. G. Laflamme, J. A. Bérubé, and R. C. Hamelin, eds. Inf. Rep. LAU-X-122. Laurentian Forestry Centre, Canadian Forest Service, Natural Resources Canada, Sainte-Foy, QC, Canada.

Innes, L., and Rainville, A. 1996. Distribution et détection du Sirococcus clavigignenti-juglandacearum au Québec. Phytoprotection 77:75-78.

Jaffa, M. A., Gebregziabher, M., Luttrell, D. K., Luttrell, L. M., and Jaffa, A. A. 2016. Multivariate generalized linear mixed models with random intercepts to analyze cardiovascular risk markers in type-1 diabetic patients. J. Appl. Stat. 43:1447-1464.

Krochmal, A., and Krochmal, C. 1982. Uncultivated Nuts of the United States. Agric. Inf. Bull. No. 450. U.S. Department of Agriculture, Washington, DC.

Kuntz, J., Prey, A., Ambuel, B., and Sarkis, E. 1977. The etiology and epidemiology of butternut canker. Proc. Am. Phytopathol. Soc. 4:84.

LaBonte, N. 2013. The influence of genetic and environmental factors on morbidity and mortality in populations of butternut affected by butternut canker disease. M.Sc. thesis, Purdue University, West Lafayette, IN.
McCleary, T. S., Robichaud, R. L., Nuanes, S., Anagnostakis, S. L., Schlarbaum, S. E., and Romero-Severson, J. 2009. Four cleaved amplified polymorphic sequence (CAPS) markers for the detection of the Juglans ailantifolia chloroplast in putatively native $J$. cinerea populations. Mol. Ecol. Resour. 9: 525-527.

McKenna, J. R., Ostry, M. E., and Woeste, K. 2011. Screening butternut and butternut hybrids for resistance to butternut canker. Pages 460-474 in: Proc. 17th Central Hardwood For. Conf. Lexington, KY. S. Fei, J. M. Lhotka, J. W. Stringer, K. W. Gottschalk and G. W. Miller, eds. U.S. Dep. Agric. For. Serv., Northern Research Station, Newtown Square, PA.

McKenney, D. W., Pedlar, J. H., Lawrence, K., Papadopol, P., Campbell, K., and Hutchinson, M. F. 2014. Change and evolution in the plant hardiness zones of Canada. Bioscience 64:341-350.

MFFPQ. 2016. Insectes, maladies et feux dans les forêts du Québec en 2015. Gouvernement du Québec, Ministère des Forêts, de la Faune et des Parcs du Québec (MFFPQ), Direction de la protection des forêts, Québec, QC, Canada.

Michler, C. H., Pijut, P. M., Jacobs, D. F., Meilan, R., Woeste, K. E., and Ostry, M. E. 2006. Improving disease resistance of butternut (Juglans cinerea), a threatened fine hardwood: A case for single-tree selection through genetic improvement and deployment. Tree Physiol. 26:121-128.

Millers, I., Lachance, D., Burkman, W. G., and Allen, D. C. 1991. North American sugar maple decline project: Organization and field methods. Gen. Tech. Rep. NE-154. U.S. Dep. Agric. For. Serv., Northeastern Forest Experiment Station, Radnor, PA and Forestry Canada, Quebec Region, Sainte-Foy, QC, Canada.

Moore, M. J., and Ostry, M. E. 2015. Influence of temperature and humidity on the viability of Ophiognomonia clavigignenti-juglandacearum conidia. Plant Dis. 99:1841-1846.

Morin, R., Beaulieu, J., Deslauriers, M., Daoust, G., and Bousquet, J. 2000 Low genetic diversity at allozyme loci in Juglans cinerea. Can. J. Bot. 78: $1238-1243$

Nair, V. M. G. 1999. Butternut canker-An international concern. Pages 239-252 in: Biotechnology and Plant Protection in Forestry Science. S. P. Raychaudhuri and K. Maramorosch, eds. Science Publishers, Enfield, NH.

Nair, V. M. G., Kostichka, C. J., and Kuntz, J. E. 1979. Sirococcus clavigignentijuglandacearum: An undescribed species causing canker on butternut. Mycologia 71:641-646.

NBDNR. 2014. Summary of Forest Pest Conditions in New Brunswick in 2013 and Outlook for 2014. New Brunswick Department of Natural Resources (NBDNR), Forest Pest Management Group, Fredericton, NB, Canada.

Nelson, B. D. 2001. Variable reduction for modeling using PROC VARCLUS Paper 261-26 in: Proc. Twenty-Sixth Annu. SAS Users Group Int. Conf. SAS Institute, Inc., Cary, NC.

Nicholls, T. H. 1979. Butternut canker. Pages 73-82 in: Proc. Symp. Walnut Insects Dis. Gen. Tech. Rep. NC-52. U.S. Dep. Agric. For. Serv., North Central Forest Experiment Station, St. Paul, MN

Nielsen, C., Cherry, M., Boysen, B., Hopkin, A., McLaughlin, J., and Beardmore, T. 2003. COSEWIC status report on the butternut Juglans cinerea in Canada Committee on the Status of Endangered Wildlife in Canada, Ottawa, ON, Canada.

Orchard, L. P., Kuntz, J. E., and Kessler, K. J. 1982. Reactions of Juglans species to butternut canker and implications for disease resistance. Pages 27-31 in: Black Walnut for the Future. Gen. Tech. Rep. NC-74. U.S. Dep. Agric. For. Serv., North Central Experiment Station, St. Paul, MN.

Ostry, M. E. 1997. Sirococcus clavigignenti-juglandacearum on heartnut (Juglans ailantifolia var. cordiformis). Plant Dis. 81:1461.

Ostry, M. E., Ellingson, B., Seekins, D., and Ruckheim, W. 2003. The need for silvicultural practices and collection of butternut germplasm for species conservation. Pages 551-555 in: Proc. 13th Central Hardwood For. Conf. J. W. Van Sambeek, J. O. Dawson, F. Ponder, Jr., E. F. Loewenstein, and J. S. Fralish, eds. Gen. Tech. Rep. NC-234. U.S. Dep. Agric. For. Serv., North Central Experiment Station, St. Paul, MN.

Ostry, M. E., Katovich, S., and Anderson, R. L. 1997. First report of Sirococcus clavigignenti-juglandacearum on black walnut. Plant Dis. 81:830.

Ostry, M. E., Mielke, M. E., and Skilling, D. D. 1994. Butternut-Strategies for managing a threatened tree. Gen. Tech. Rep. NC-165. U.S. Dep. Agric. For. Serv., North Central Forest Experiment Station, St. Paul, MN.

Ostry, M. E., and Moore, M. 2007. Natural and experimental host range of Sirococcus clavigignenti-juglandacearum. Plant Dis. 91:581-584.

Ostry, M. E., and Woeste, K. 2004. Spread of butternut canker in North America, host range, evidence of resistance within butternut populations and conservation genetics. Pages 114-120 in: Black Walnut in a New Century. Proc. 6th Walnut Council Res. Symp. C. H. Michler, P. M. Pijut, J. W. Van Sambeek, M. V. Coggeshall, J. Seifert, K. Woeste, R. Overton, and F. Ponder, Jr., eds. Gen. Tech. Rep. NC-243. U.S. Dep. Agric. For. Serv., North Central Research Station, St. Paul, MN.

Parks, A., Jenkins, M., Ostry, M., Zhao, P., and Woeste, K. 2014. Biotic and abiotic factors affecting the genetic structure and diversity of butternut in the southern Appalachian Mountains, USA. Tree Genet. Genomes 10:541-554.

Parks, A. M., Jenkins, M. A., Woeste, K. E., and Ostry, M. E. 2013. Conservation status of a threatened tree species: Establishing a baseline for restoration of Juglans cinerea L. in the southern Appalachian mountains, USA. Nat. Areas J. 33:413-426. 
Pijut, P. M. 1993. Somatic embryogenesis in butternut, Juglans cinerea. Can. J. For. Res. 23:835-838.

Régnière, J. 1996. Generalized approach to landscape-wide seasonal forecasting with temperature-driven simulation models. Environ. Entomol. 25:869-881.

Régnière, J., and St-Amant, R. 2007. Stochastic simulation of daily air temperature and precipitation from monthly normals in North America north of Mexico. Int. J. Biometeorol. 51:415-430.

Renlund, D. W., ed. 1971. Forest pest conditions in Wisconsin. Pages 26-28 in: Annual Report 1971. Wisconsin Department of Natural Resources, Madison.

Rink, G. 1990. Juglans cinerea L. Butternut. Pages 386-390 in: Silvics of North America, Vol. 2. Hardwoods. R. M. Burns and B. H. Hionkala, [tech. coords.] eds. U.S. Dep. Agric. For. Serv. Agric. Handb. No. 654. U.S. Department of Agriculture, Washington, DC.

Ross-Davis, A., Huang, Z., McKenna, J., Ostry, M., and Woeste, K. 2008. Morphological and molecular methods to identify butternut (Juglans cinerea) and butternut hybrids: Relevance to butternut conservation. Tree Physiol. 28: 1127-1133.

Schlarbaum, S. E., Anderson, R. L., Ostry, M. E., Brosi, S. L., Thompson, L. M., Clark, S. L., van Manen, F. T., Spaine, P. C., Young, C., Anagnostakis, S. A., and Brantley, E. A. 2004. An integrated approach for restoring butternut to eastern North American forests. Pages 156-158 in: Forest Genetics and Tree Breeding in the Age of Genomics: Progress and Future. B. Li and $\mathrm{S}$. McKeand, eds. IUFRO Joint Conference of Division 2, Charleston, SC.
Thompson, L. M., van Manen, F. T., Schlarbaum, S. E., and DePoy, M. 2006. A spatial modeling approach to identify potential butternut restoration sites in Mammoth Cave National Park. Restor. Ecol. 14:289-296.

Tisserat, N., and Kuntz, J. E. 1983a. Dispersal gradients of conidia of the butternut canker fungus in a forest during rain. Can. J. For. Res. 13:1139-1144.

Tisserat, N., and Kuntz, J. E. 1983b. Longevity of conidia of Sirococcus clavigignenti-juglandacearum in a simulated airborne state. Phytopathology 73:1628-1631.

Tisserat, N., and Kuntz, J. E. 1984. Butternut canker: Development on individual trees and increase within a plantation. Plant Dis. 68:613-616.

Van Sambeek, J. W., Ostry, M. E., and Zaczek, J. J. 2003. Survival and growth of deep-planted, in-leaf grafts in a germplasm repository of canker-resistant butternut. Pages 476-479 in: Proc. 13th Central Hardwood Forest Conf. J. W. Van Sambeek, J. O. Dawson, F. Ponder, Jr., E. F. Loewenstein, and J. S. Fralish, eds. Gen. Tech. Rep. NC-234. U.S. Dep. Agric. For. Serv., North Central Forest Experiment Station, St. Paul, MN

Voglmayr, H., Castlebury, L. A., and Jaklitsch, W. M. 2017. Juglanconis gen. nov. on Juglandaceae, and the new family Juglanconidaceae (Diaporthales). Persoonia 38:136-155.

Woeste, K., Farlee, L., Ostry, M., McKenna, J., and Weeks, S. 2009. A forest manager's guide to butternut. North. J. Appl. For. 26:9-14.

Woeste, K., and Pijut, P. M. 2009. The peril and potential of butternut. Arnoldia 66:2-12

Zar, J. H. 1999. Biostatistical Analysis, 4th ed. Prentice-Hall, Upper Saddle River, NJ. 